\title{
CLINICAL USE OF STEM CELLS IN ORTHOPAEDICS
}

\author{
G-I. Im* \\ Department of Orthopaedics, Dongguk University Ilsan Hospital, Goyang, Republic of Korea.
}

\begin{abstract}
Stem cell research arose from the need to explore new therapeutic possibilities for intractable and lethal diseases. Although musculoskeletal disorders are basically nonlethal, their high prevalence and relative ease of performing clinical trials have facilitated the clinical application of stem cells in this field. However, few reliable clinical studies have been published, despite the plethora of in vitro and preclinical studies in stem cell research for regenerative medicine in the musculoskeletal system. Stem cell therapy can be applied locally for bone, cartilage and tendon regeneration. Candidate disease modalities in bone regeneration include large bone defects, nonunion of fractures, and osteonecrosis. Focal osteochondral defect and osteoarthritis are current targets for cartilage regeneration. For tendon regeneration, bone-tendon junction problems such as rotator cuff tears are hot topics in clinical research. To date, the literature supporting stem cell-based therapies comprises mostly case reports or case series. Therefore, high-quality evidence, including from randomised clinical trials, is necessary to define the role of cell-based therapies in the treatment of musculoskeletal disorders. It is imperative that clinicians who adopt stem cell treatment into their practices possess a good understanding of the natural course of the disease. It is also highly recommended that treating physicians do not thrust aside the concomitant use of established measures until stem cell therapy is evidently proved worthy in terms of efficacy and cost. The purpose of this review is to summarise on the current status of stem cell application in the orthopaedic field along with the author's view of future prospects.
\end{abstract}

Keywords: Stem cells, cartilage, tendon, regeneration, therapy, orthopaedics, clinic.

\author{
*Address for correspondence: \\ Gun-Il Im, MD \\ Department of Orthopaedics \\ Dongguk University Ilsan Hospital \\ 814 Siksa-Dong, Goyang, 410-773, Republic of Korea
}

Telephone: +82319617315

Fax +82319617314

E-mail: gunil@dumc.or.kr

\section{Introduction}

Orthopaedic medicine has traditionally benefited from innovations in other fields of science. Development of metal and chemical engineering in the early $20^{\text {th }}$ century contributed to current orthopaedic practice, as various implants based on newly developed biomaterials were devised and applied to patients. Recent advances in regenerative medicine have opened a new horizon in orthopaedics and may in future shift the paradigm in clinical practice. Diseases currently managed by surgical treatment may be more effectively and more economically treated by less-invasive procedures, such as simple injection of cells.

Stem cell research arose from the need to explore new therapeutic possibilities for intractable and lethal diseases. In the orthopaedic field, diseases which current treatment modalities do not offer satisfactory, efficient or durable results for have been targets of stem cell treatment (Sampson et al., 2015). While complete regeneration usually occurs after bone injury, critical size defects of long bone requires either harvesting a large portion of autograft with significant morbidity or allograft implantation that is associated with several complications. Osteonecrosis of the femoral head (ONFH), which causes the collapse of femoral head and secondary osteoarthritis of the hip joint, leads to premature total hip arthroplasty (THA) in young patients. Nonunion of long bone still often presents a dilemma in achieving a bony union (Im, 2015). Stem cell treatment may provide an innovative therapy for these lesions. Unlike bone, which is self-regenerating tissue, articular cartilage (AC) has limited potential for self-regeneration, and damage to $\mathrm{AC}$ eventually leads to the development and progression of osteoarthritis (OA) (Im, 2016; Vinatier et al., 2009). As the defect of $\mathrm{AC}$ is not amenable to conventional procedures such as microfracture, it can be a good candidate for regenerative therapy with stem cell implantation. More diffuse damage of AC, seen in OA, may also become a target of stem cell therapy because the current treatment modalities do not offer a regenerative option for patients. Other candidates for stem cell treatment are degenerative tendon disorders, including advanced rotator cuff tears, which are not successfully treated by repair techniques (Gomes et al., 2012).

The two most common sources of adult stem cells for clinical application in orthopaedics are bone marrow and adipose tissue. Both bone marrow aspirate and lipoaspirate contain different cell fractions. When bone marrow aspirate is centrifuged, bone marrow aspirate concentrate (BMAC) can be obtained from buffy-coat layer which contains mononuclear cells including very 
low percentage of mesenchymal stem cells (MSCs). When lipoaspirate is treated by enzymes and undergoes differential centrifugation, fat and mature adipocytes in the upper layer are separated. The bottom layer is stromal vascular fraction (SVF) that contains low percentage of MSCs. When BMAC and SVF are put into a monolayer culture on plastic dishes and passaged, cells that have characteristics of MSCs can be isolated.

Although musculoskeletal disorders are basically nonlethal, their high prevalence and relative ease of performing clinical trials have facilitated the clinical application of stem cells in this field. However, few reliable clinical studies have been published, despite the plethora of in vitro and preclinical studies in stem cell research for regenerative medicine in the musculoskeletal system. While randomised controlled clinical trials undoubtedly would produce the most reliable data, they are difficult to conduct because of high cost related to performing those studies. Therefore, most clinical data comes from case reports/cohort outcome studies which have problems in reproducibility and should be interpreted with caution. In this review, the current status of stem cell application in the clinical field is introduced, together with the author's view of future prospects.

\section{Search for articles}

Searches were performed using PubMed and Google Scholar to identify both original and review articles to ensure inclusion of pertinent data. Key words used included stem cell, mesenchymal stem cell, bone marrow, adipose tissue, clinical application, treatment, bone defect, segmental bone defect, osteonecrosis, avascular necrosis, fracture healing, nonunion, osteochondral defect, cartilage repair, cartilage defect, osteoarthritis, rotator cuff and tendinopathy. The articles were downloaded directly from publishers or other online resources. The articles were then reviewed for additional references and originality. Primarily, the methodology and results were extracted from each pertinent scientific article and only clinical data were included in the review (Murrell et al., 2015).

\section{Stem cell application for bone regeneration}

\section{Stems cells for treating long-bone defects}

Bone is one of the most frequently transplanted tissues (Giannoudis et al., 2005). Unlike other tissues, complete regeneration occurs after bone injury, rather than healing with scar tissue. While most bone defects heal spontaneously or with autogenous bone grafting, critical size defects of long bone caused by major trauma or resection of malignant tumours pose a challenge in treatment. To treat a large bone defect, harvesting a large portion of bone from other parts of the body inevitably creates significant morbidity at the donor site (Sen and Miclau, 2007). Allografts from cadavers carry a risk of infection and disease transmission, as well as failure to incorporate into host bone if used in bulk (Aro and Aho, 1993; Tomford et al., 1981). Bone substitute materials have limited osteogenic potential, and are not useful for complex bone reconstructions ( $\mathrm{Im}, 2013)$. To facilitate regeneration of currently intractable large bone defects, stem cell therapy has emerged as a possible solution. Bone marrow injection, in a sense, represents a primitive form of stem cell therapy. The method had been used to treat long-bone defects and enhance fracture repair prior to establishment of the concept of stem cells (Healey et al., 1990; Tiedeman et al., 1991). However, because various cells are present in bone marrow aspirate, a small proportion of which are stem cells, it cannot be truly categorised as a stem cell therapy.

Most reported human studies of stem cell-based bone regeneration are cohort outcome studies or case reports, because of the practical and ethical issues involved in conducting a randomised controlled trial (Table 1). Published human clinical studies or case reports used autologous, culture-expanded, non-genetically modified human MSCs for bone regeneration. While the absence of controls is a major drawback, these preliminary cohort

Table 1. Use of stems cells for treating long bone defects.

\begin{tabular}{|c|c|c|c|c|}
\hline References & $\begin{array}{l}\text { Form of reports } \\
\text { (number of patients): } \\
\text { Level of evidence }\end{array}$ & Used cells & Applied bone defects & $\begin{array}{l}\text { Carrier or additional } \\
\text { substances }\end{array}$ \\
\hline $\begin{array}{l}\text { (Healey et } \\
\text { al., 1990) }\end{array}$ & $\begin{array}{l}\text { Case reports (8): } \\
\text { Level } 4\end{array}$ & Autologous bone marrow aspirate & $\begin{array}{l}\text { Diaphyseal non-union after } \\
\text { tumour resection }\end{array}$ & \\
\hline $\begin{array}{l}\text { (Quarto et al., } \\
\text { 2001) }\end{array}$ & $\begin{array}{l}\text { Case reports ( } 3) \text { : } \\
\text { Level } 4\end{array}$ & $\begin{array}{l}\text { Culture-expanded autologous } \\
\text { MSCs }\end{array}$ & $\begin{array}{l}\text { Diaphyseal defects (Tibia; } \\
\text { humerus, ulna) }\end{array}$ & $\begin{array}{l}\text { Macroporous hydroxyapatite } \\
\text { scaffolds }\end{array}$ \\
\hline $\begin{array}{l}\text { (Stres et al., } \\
2007)\end{array}$ & $\begin{array}{l}\text { Case report (1): } \\
\text { Level } 4\end{array}$ & $\begin{array}{l}\text { Mixed autologous cancellous bone } \\
\text { and culture-expanded autologous } \\
\text { MSCs }\end{array}$ & Femoral diaphyseal defect & $\begin{array}{l}\text { Porous calcium-triphosphate } \\
\text { granules }\end{array}$ \\
\hline $\begin{array}{l}\text { (Hibi et al., } \\
\text { 2006) }\end{array}$ & $\begin{array}{l}\text { Case report (1): } \\
\text { Level } 4\end{array}$ & $\begin{array}{l}\text { Culture-expanded autologous } \\
\text { MSCs and PRP }\end{array}$ & Mandibular defect & $\begin{array}{l}\text { Calcium chloride and titanium } \\
\text { mesh }\end{array}$ \\
\hline $\begin{array}{l}\text { (Meijer et al., } \\
\text { 2008) }\end{array}$ & $\begin{array}{l}\text { Case report (6): } \\
\text { Level } 4\end{array}$ & $\begin{array}{l}\text { Culture-expanded autologous } \\
\text { MSCs }\end{array}$ & Alveolar cavitary defects & Hydroxyapatite granule \\
\hline $\begin{array}{l}\text { (Mesimaki et } \\
\text { al., 2009) }\end{array}$ & $\begin{array}{l}\text { Case report (1): } \\
\text { Level } 4\end{array}$ & $\begin{array}{l}\text { Culture-expanded autologous } \\
\text { ASCs }\end{array}$ & Maxillary defects & Titanium cage, BMP and $\beta$-TCP \\
\hline $\begin{array}{l}\text { (Shayesteh et } \\
\text { al., 2008) }\end{array}$ & $\begin{array}{l}\text { Case report (7): } \\
\text { Level } 4\end{array}$ & $\begin{array}{l}\text { Culture-expanded autologous } \\
\text { MSCs }\end{array}$ & Maxillary Sinus & Hydroxyapatite/ $\beta$-TCP \\
\hline $\begin{array}{l}\text { (Dufrane et } \\
\text { al., 2015) }\end{array}$ & $\begin{array}{l}\text { Case report (6): } \\
\text { Level } 4\end{array}$ & $\begin{array}{l}\text { Culture-expanded autologous } \\
\text { ASCs }\end{array}$ & $\begin{array}{l}\text { Diaphyseal defects (3), } \\
\text { pseudoarthrosis (3) }\end{array}$ & Scaffold-free 3-dimensional \\
\hline
\end{tabular}


studies hint at the safety and potential therapeutic effects of autologous stem cell treatment (Dufrane et al., 2015; Im, 2015; Quarto et al., 2001).

The first clinical case report described three patients with various segmental long bone defects who underwent implantation of autologous MSCs (Quarto et al., 2001). Macroporous $100 \%$ hydroxyapatite (HA) scaffolds, which were made to fit the shape and size of the defect, were loaded with ex vivo-expanded hMSCs isolated from their own bone marrow and implanted into the long-bone defects. After follow-up of 6-7 years, the implants were integrated into the bone with no further complications. Despite the lack of controls and no evaluation other than simple radiographs, this report demonstrated the safety of the procedure. In another report, one patient with a comminuted fracture of femur was treated using a combination of autologous cancellous bone and stem cell-seeded porous calcium-triphosphate granules at a ratio of 1:2 (Stres et al., 2007). Other clinical studies are case reports on reconstruction of maxillary or mandibular defect using various scaffolding materials, including fibrin glue, $\beta$-tricalcium phosphate $(\beta$-TCP) or HA granules, and platelet-rich plasma (Correia et al., 2011; Hibi et al., 2006; Meijer et al., 2008; Mesimaki et al., 2009; Shayesteh et al., 2008).

Studies to date show the safety of using autologous hMSCs for bone regeneration in segmental long-bone defects. None of the reports mention adverse effects, such as inflammation or excessive tissue growth. In view of the report that extensively cultured MSCs (4-5 months) can develop genomic instability, an indicator of malignant transformation (Røsland et al., 2009; Rubio et al., 2005), the relatively short in vitro expansion period (6-8 weeks) may account for the lack of reported malignancy in the clinical studies performed so far (Im, 2015).

Recently, Dufrane et al. reported use of scaffold-free three-dimensional (3D) grafts from autologous adipose stem cells (ASCs) for reconstruction of large-bone defects. hASCs were obtained from subcutaneous adipose tissue of six patients, expanded up to passage 4 , incubated in osteogenic medium supplemented with demineralised bone matrix (DBM) to generate the scaffold-free 3D osteogenic structure. The 3D 'bone-like' structure was finally transplanted into three patients with bone tumour resection and three patients with bone pseudoarthrosis (two congenital, one acquired). The final osteogenic product was implanted directly into the bone defect. In three patients who had achieved consolidation, no acute ( $<3$ months) side effects, such as impaired wound healing, pain, inflammatory reaction, and infection; or long-term side effects, such as tumour development, were associated with the graft up to 4 years after transplantation (Dufrane et al., 2015).

In summary, because of challenging nature of constructing a viable cell-scaffold composite, clinical application of stem cell is still in its incipient stage. Sporadic reports describe the application of MSCs from bone marrow or adipose tissue along with various scaffolding materials to treat long bone defects. While complete regeneration of bone in the large defects was demonstrated in those reports, it is still premature to draw conclusion on their safety and efficacy with the absence of controlled trials.

\section{Application of stem cells for osteonecrosis}

ONFH is the death of osteocytes and subsequent structural change leading to collapse of femoral head and secondary osteoarthritis of the hip joint (Jones, 1994). ONFH occurs in the young, necessitating premature total hip arthroplasty (THA). Various treatment modalities including core decompression and rotational osteotomy have been developed to preserve the femoral head in ONFH. In core decompression, part of necrotic bone is removed to decompress the intramedullary pressure and thereby relieve pain. Because of the relative insufficiency of osteoprogenitor cells in the proximal femur of the osteonecrotic hip (Hernigou et al., 2005), the bone defect thus created is not rapidly filled with new bone and the femoral head ultimately undergoes collapse (Koo et al., 1995). In rotational osteotomy, the proximal femur is osteotomised and rotated along the axis of the femoral neck, so that the uninvolved posterior portion becomes the superior weight-bearing area (Sugioka, 1978). This operation has not been popularised outside of Japan due to technical difficulties and poor results (Eyb and Kotz, 1987). A method that induces bone regeneration with minimal surgical intervention is needed for those young patients (Im, 2015). Hernigou et al. first hit on the idea of cell therapy for ONFH. They added BMAC to core decompression (Hernigou and Beaujean, 2002). A series of publications reported positive results of BMAC implantation for treatment of ONFH (Gangji et al., 2011; Hernigou et al., 2009). As mentioned previously, BMAC is a mixture of various mononuclear cells, of which a very small fraction $(0.01 \%)$ comprises MSCs (Jones et $a l ., 2006)$. Furthermore, the number of stem cells in the final preparation varies among patients, and thus cannot be standardised. Following studies, using ex vivo expanded autologous MSCs, yielded similar success to BMAC (Gangji and Hauzeur, 2009; Kawate et al., 2006).

Several controlled studies have been published recently on the application of BMACs to treat ONFH, most of which reported a beneficial effect of the implantation of BMACs or culture-expanded MSCs (Table 2). Sen et al. performed a randomised clinical trial on 51 osteonecrotic hips in 40 patients. Twenty-five hips were treated with core decompression, and 26 hips received autologous BMAC instillation into the core tract after core decompression. After 12 and 24 months, the clinical score and mean hip survival were significantly better in the hips that underwent additional BMAC treatment (Sen et al., 2012). Ma et al. performed a prospective, double-blinded, randomised and controlled study of the effect of bone-marrow buffy coat (BBC) grafting. Forty-five patients (53 hips) with Ficat stage I to III (Ficat, 1985) ONFH were recruited. The hips were allocated to the control group (core decompression + autologous bone graft) or treatment group (core decompression + autologous bone graft with BBC). After 24 months, there was significant relief of pain and clinical joint symptoms in the treatment group. In addition, $33.3 \%$ of hips in the control group deteriorated to the next stage, whereas only $8 \%$ in the treatment group had 
Table 2. Application of stem cells to treat osteonecrosis.

\begin{tabular}{|c|c|c|c|c|}
\hline References & $\begin{array}{l}\text { Form of reports (number of } \\
\text { patients): Level of evidence }\end{array}$ & Used cells & $\begin{array}{l}\text { Additional procedure / } \\
\text { carrier or additional } \\
\text { substances }\end{array}$ & Key results \\
\hline $\begin{array}{l}\text { (Hernigou and } \\
\text { Beaujean, 2002) }\end{array}$ & $\begin{array}{l}\text { Case series (116,186 hips): } \\
\text { Level } 4\end{array}$ & BMAC & & $\begin{array}{l}\text { THA in } 9 \text { of } 145 \text { Stage I, II hip, } 25 \text { of } 44 \text { hips in } \\
\text { Stage III, IV hips. }\end{array}$ \\
\hline $\begin{array}{l}\text { (Gangji et al., } \\
\text { 2011) }\end{array}$ & $\begin{array}{l}\text { Prospective controlled study } \\
(19,26 \text { hips, all Stage I,II): } \\
\text { Level } 2\end{array}$ & BMAC & & $\begin{array}{l}8 \text { of } 11 \text { hips progressed in control group, } 3 \text { of } 13 \\
\text { hips in graft group progressed. }\end{array}$ \\
\hline $\begin{array}{l}\text { (Hernigou et al., } \\
\text { 2009) }\end{array}$ & $\begin{array}{l}\text { Case series }(342,534 \text { hips }): \\
\text { Level } 4\end{array}$ & BMAC & & THA in 94 of the 534 Stage I, II hips. \\
\hline (Sen et al., 2012) & $\begin{array}{l}\text { Prospective randomised trial } \\
(40,51 \text { hips, all Stage I, II): } \\
\text { Level } 4\end{array}$ & BMAC & & $\begin{array}{l}\text { After } 12 \text { and } 24 \text { months, clinical score and mean } \\
\text { hip survival significantly better with BMAC. }\end{array}$ \\
\hline (Ma et al., 2014) & $\begin{array}{l}\text { Prospective randomised trial } \\
(45,53 \text { hips }): \text { Level } 4\end{array}$ & BMAC & $\begin{array}{l}\text { Autologous bone graft for } \\
\text { both groups }\end{array}$ & $\begin{array}{l}\text { Non-progression rates for stage I/II hips were } \\
100 \% \text { in the treatment group and } 66.7 \% \text { in the } \\
\text { control group. }\end{array}$ \\
\hline $\begin{array}{l}\text { (Zhao et al., } \\
\text { 2012) }\end{array}$ & $\begin{array}{l}\text { Prospective randomised trial } \\
\text { (100): Level } 1\end{array}$ & $\begin{array}{l}\text { Culture- } \\
\text { expanded } \\
\text { BMSCs }\end{array}$ & & $\begin{array}{l}\text { After } 5 \text { years, } 2 \text { of the } 53 \text { MSC-treated hips } \\
\text { progressed. In control group, } 10 \text { of } 44 \text { hips } \\
\text { progressed. }\end{array}$ \\
\hline $\begin{array}{l}\text { (Lim et al., } \\
\text { 2013) }\end{array}$ & $\begin{array}{l}\text { Case control study } \\
(128,190 \text { hip): Level } 3\end{array}$ & BMAC & $\begin{array}{l}\text { Fibrin glue in stem cell } \\
\text { group, autologous bone } \\
\text { graft for control group }\end{array}$ & $\begin{array}{l}\text { Higher success rate in Stage I, II than Stage III } \\
\text { lesions. Essentially the same results as in the } \\
\text { control group. }\end{array}$ \\
\hline $\begin{array}{l}\text { (Kang et al., } \\
\text { 2013) }\end{array}$ & $\begin{array}{l}\text { Case series (52, } 61 \text { hips): } \\
\text { Level } 4\end{array}$ & BMAC & $\begin{array}{l}\text { Autologous bone graft for } \\
\text { both groups }\end{array}$ & $\begin{array}{l}\text { High failure rates in Stage III, IV, large lesions or } \\
\text { medium-sized laterally located lesions. }\end{array}$ \\
\hline $\begin{array}{l}\text { (Persiani et al., } \\
\text { 2015) }\end{array}$ & $\begin{array}{l}\text { Case series }(29,31 \text { hips }) \text { : } \\
\text { Level } 4\end{array}$ & $\begin{array}{l}\text { Culture- } \\
\text { expanded } \\
\text { BMSCs } \\
\end{array}$ & & $\begin{array}{l}\text { Symptom relief and resolution of ONFH in } 25 \\
\text { hips ( } 11 \text { Stage I, } 14 \text { Stage II). Progression in } 6 \\
\text { hips ( } 2 \text { Stage II, } 2 \text { Stage III and } 2 \text { Stage IV). }\end{array}$ \\
\hline $\begin{array}{l}\text { (Martin et al., } \\
\text { 2013) }\end{array}$ & $\begin{array}{l}\text { Case series (77 hips, all Stage } \\
\text { I,II): Level } 4\end{array}$ & BMAC & PRP & $\begin{array}{l}16 \text { hips }(21 \%) \text { progressed. Significant pain relief } \\
\text { in } 60(86 \%) \text { of patients. }\end{array}$ \\
\hline $\begin{array}{l}\text { (Mao et al., } \\
\text { 2013) }\end{array}$ & $\begin{array}{l}\text { Case series (62, } 78 \text { hips, all } \\
\text { Stage I,II): Level } 4\end{array}$ & BMAC & Intra-arterial injection & $\begin{array}{l}72 \text { of } 78 \text { hips had a satisfactory clinical result. } 6 \\
\text { hips progressed and required THA. }\end{array}$ \\
\hline $\begin{array}{l}\text { (Mao et al., } \\
\text { 2015) }\end{array}$ & $\begin{array}{l}\text { Prospective randomised trial } \\
(55,98 \text { hips, Stage I to III): } \\
\text { Level I }\end{array}$ & PBSCs & $\begin{array}{l}\text { Porous tantalum rod im- } \\
\text { plantation for both group, } \\
\text { intra-arterial injection }\end{array}$ & $\begin{array}{l}\text { The overall collapse rates were } 15.15 \%(5 / 33 \\
\text { hips) and } 8.11 \%(3 / 37 \text { hips }) \text { in the control and } \\
\text { combination treatment groups. }\end{array}$ \\
\hline $\begin{array}{l}\text { (Hernigou et al., } \\
\text { 1997) }\end{array}$ & Case report (1): Level 4 & BMAC & & Total repair of ONFH after 4 years \\
\hline $\begin{array}{l}\text { (Daltro et al., } \\
\text { 2015) }\end{array}$ & $\begin{array}{l}\text { Cohort study (89, all Stage I or } \\
\text { II): Level } 2\end{array}$ & BMAC & & $\begin{array}{l}\text { Significant improvement in symptoms and } \\
\text { radiological finding in } 86 \text { patients. }\end{array}$ \\
\hline $\begin{array}{l}\text { (Kawate et al., } \\
\text { 2006) }\end{array}$ & $\begin{array}{l}\text { Case series (45, all } \geq \text { stage III): } \\
\text { Level } 4\end{array}$ & \begin{tabular}{|l|} 
Culture- \\
expanded \\
autologous \\
BMSCs \\
\end{tabular} & $\begin{array}{l}\text { Free fibular graft and } \\
\beta \text {-TCP granules }\end{array}$ & $\begin{array}{l}\text { Osteonecrosis did not progress any further and } \\
\text { early bone regeneration was observed. }\end{array}$ \\
\hline $\begin{array}{l}\text { (Aoyama et al., } \\
\text { 2014) }\end{array}$ & $\begin{array}{l}\text { Case series (10, all stage III): } \\
\text { Level } 4\end{array}$ & $\begin{array}{l}\text { Culture- } \\
\text { expanded } \\
\text { autologous } \\
\text { BMSCs }\end{array}$ & $\begin{array}{l}\text { Vascularised iliac bone } \\
\text { graft and } \beta \text {-TCP granules }\end{array}$ & $\begin{array}{l}\text { Of } 9 \text { patients who completed the protocol, } 7 \\
\text { remained at Stage III, and the remaining } 2 \text { cases } \\
\text { progressed to Stage IV. The average bone volume } \\
\text { increased. }\end{array}$ \\
\hline
\end{tabular}

further deterioration. The non-progression rates for stage I/II hips were $100 \%$ in the treatment group and $66.7 \%$ in the control group (Ma et al., 2014). Zhao et al. recruited 100 patients with early stage ONFH, who were randomly assigned to bone marrow-derived MSC (BMSC) treatment or core decompression treatment. Each BMSC-treated hip was implanted with $2 \times 10^{6}$ autologous ex vivo-expanded cells. Sixty months after the operation, only 2 of the 53 BMSC-treated hips progressed, while 10 of 44 hips progressed in the core decompression group. Compared with the core decompression group, BMSC treatment significantly improved the Harris hip score and decreased the volume of necrotic lesions of the femoral head (Zhao et al., 2012).

On the other hand, Lim et al. reported negative clinical and radiological results of stem cell implantation and core decompression. In total, 128 patients (190 hips) who had undergone surgery were divided into the following two treatment groups: (1) multiple drilling and stem cell implantation and (2) core decompression, curettage and a bone graft. Success rates were higher in patients with Ficat Stage I or II lesions than in those with Stage III lesions in both groups. There were no significant differences between the groups in terms of success rate or in the clinical and radiographic results of the two methods (Lim et al., 2013). Other groups reported various results from uncontrolled studies. Kang et al. prospectively evaluated the clinical results of 61 hips with auto-iliac cancellous bone grafts combined with implantation of autologous BMAC for ONFH. Patients with large lesions or medium-sized laterally located lesions showed high failure rates $(76.5 \%)$ (Kang et al., 2013). Persiani et al. analysed the clinical outcome of a series of 29 patients (31 hips) affected by ONFH and treated with the core-decompression technique and BMSC implantation. The treatment led to a significant decrease in joint pain level and a success in avoiding or delaying the need for hip replacement in the early stages (Persiani et al., 2015). Martin et al. used BMAC and platelet-rich plasma (PRP) during minimally invasive decompression of the femoral head in the treatment of 
ONFH at Ficat Stage I or II. Significant pain relief was reported in $86 \%$ of patients $(n=60)$ (Martin et al., 2013).

In addition to direct cell placement by surgery, one group attempted targeted intra-arterial delivery of BMAC in the treatment of ONFH. Sixty-two patients (78 hips) with ONFH were recruited and were treated with BMAC perfusion via the medial circumflex femoral artery. After 5 years, $92.31 \%$ (72 of 78 ) of hips achieved a satisfactory clinical result while only 6 hips $(7.69 \%)$ progressed to clinical failure and required THA (Mao et al., 2013). The same group performed a randomised controlled clinical trial of combination treatment of biomechanical support (porous tantalum rod implantation) and targeted intraarterial infusion of peripheral blood stem cells (PBSCs) mobilised by granulocyte-colony stimulating factor in ONFH. At 36 months, 9 of the 41 hips $(21.95 \%)$ in the control group (porous tantalum rod implantation only) progressed to clinical failure and underwent THA, whereas only 3 of the 48 hips $(6.25 \%)$ in the combination treatment group required THA ( $p=0.031)$ (Mao et al., 2015).

Stem cell therapy has been also assessed in unusual forms of osteonecrosis, such as sickle cell disease. Hernigou et al. administered allogeneic stem cells by the intravenous route in a patient who had osteonecrosis of the humeral head secondary to sickle-cell disease, leading to a favourable outcome and total repair of the osteonecrosis after a follow-up of 4 years (Hernigou et al., 1997). Daltro et al. conducted a phase I/II, non-controlled study to determine the efficacy and safety of BMAC implantation using a minimally invasive technique in 89 sickle cell disease patients with ONFH. At the final follow-up (60 months) there was a significant improvement in clinical joint symptoms and pain relief. In addition, radiographic assessment after the BMAC implantation procedure showed disease stabilisation (Daltro et al., 2015).

Scaffolds in the form of hydrogel or solid forms help to retain the cells at the lesion site and promote osteoconduction or osteoinduction. The use of fibrin glue, porous hydroxyapatite composite, and $\beta$-TCP ceramic chips have been reported along with BMAC or expanded MSCs (Kawate et al., 2006; Lim et al., 2013). Aoyama et al. performed an exploratory clinical trial for advanced-stage ONFH using cultured autologous MSCs $\left(0.5-1.0 \times 10^{8}\right)$ mixed with $\beta$-TCP granules augmented with vascularised bone grafts. After 24 months, the average bone volume increased and the average clinical score improved. Some young patients with extensive necrotic lesions with pain demonstrated good bone regeneration with amelioration of symptoms (Aoyama et al., 2014).

Summing up, most of reported studies are uncontrolled case series although there are a few controlled studies. Local implantation of BMAC to core decompression tract was most commonly used while some of recent studies used culture-expanded BMSCs. Scaffolding materials include fibrin glue, PRP, $\beta$-TCP, autologous bone and tantalum rod. While it is difficult to compare individual studies because of heterogeneous methods of application, BMAC or BMSC treatment seems to have reasonable, if not remarkable, effects in early stage (Ficat I or II) ONFH in terms of symptomatic relief and preventing progression of femoral head collapse.

\section{Stem cells for fracture healing}

Nonunion occurs when a fracture has failed to heal in the expected time. Because the expected time is hard to define and arbitrary, it is better defined as when further progress in bone healing will not occur without intervention (Bolhofner, 2010). Nonunion of fracture may be caused by uncontrolled movement of the fracture site or by acellular environment. Bone marrow aspirate from the iliac crest has been applied to nonunion sites with limited morbidity (Gomez-Barrena et al., 2011). Twenty patients who had delayed union were injected with bone marrow nonunion, with a mean of 9.65 months between initial surgery and marrow injection. Of the 20 fractures, 19 achieved clinical and radiological union, on average after 2.95 months (Connolly et al., 1991). Another study showed that after percutaneous bone marrow injection $(15-20 \mathrm{~mL}$ twice) in 20 cases of ununited fractures of long bone, 17 cases $(85 \%)$ had successful union in 5 months (Garg et al., 1993). Of 11 patients with prior plating who had nonunion or delayed union of the distal tibial metaphysis and had additional percutaneous autologous bone marrow injection, nine attained bony union within 6 months of bone marrow injection. Various aspirations and cell concentration techniques have been reported to increase the number of progenitor cells, with reported union rates ranging from $62.5 \%$ to $90 \%$ (Ateschrang et al., 2009; Dallari et al., 2007; Gan et al., 2008; Kitoh et al., 2007; Neen et al., 2006).

Use of BMAC or BMSCs in combination with other osteoconductive or osteoinductive substances has been reported on diverse condition. A prospective, randomised, controlled study assessed the use of autologous MSCs to enhance the healing of osteotomies in 33 patients undergoing a high tibial osteotomy (HTO) to treat genu varum. At the final evaluation at 1 year, osseointegration was superior with the combined use of platelet or platelet gel and BMSCs with lyophilised bone chips on the osteotomy site than with lyophilised bone chips alone (Dallari et al., 2007). Rodriguez-Collazo et al. reported combined use of the Ilizarov external fixation, BMAC and PRP to expedite healing of bimalleolar fractures. Ten patients were in the BMAC group, and 10 patients were in the control group. Radiographs in the BMAC group showed a significant difference in the rate of complete healing at $16 \pm 1.6$ weeks post-surgery as compared to $24 \pm 1.3$ weeks in the control group (Rodriguez-Collazo and Urso, 2015). Desai et al. performed non-randomised retrospective-prospective cohort study with 49 patients who had tibial nonunion. Patients underwent BMAC injection with DBM and/or recombinant human bone morphogenic protein-2 (rhBMP-2). On multivariate analysis, the use of rhBMP-2 was associated with a lower healing rate compared to DBM. Patients who underwent early intervention (within 6 months of fixation) had higher union rates (Desai et al., 2015). Murena et al. reported use of an opposite cortical allograft combined with BMP-7 and BMAC to treat humeral shaft atrophic nonunions in two elderly patients. The nonunion site healed at 4 months and 8 months postoperatively, with full return to activities of daily living and no pain (Murena et al., 2014). Qu et al. reported a retrospective study of cell therapy for bone 
Table 3. Use of stem cells for fracture healing.

\begin{tabular}{|c|c|c|c|c|}
\hline References & $\begin{array}{l}\text { Form of reports } \\
\text { (number of patients): } \\
\text { Level of evidence }\end{array}$ & Used cell & Applied bone defects & Key results \\
\hline $\begin{array}{l}\text { (Connolly et } \\
\text { al., 1991) }\end{array}$ & Case series (20): Level 4 & Autologous bone marrow aspirate & $\begin{array}{l}20 \text { ununited tibial } \\
\text { fractures }\end{array}$ & $\begin{array}{l}\text { Of the } 20 \text { fractures, } 19 \text { achieved } \\
\text { clinical and radiological union, } \\
\text { on average after } 2.95 \text { months. }\end{array}$ \\
\hline $\begin{array}{l}\text { (Garg et al., } \\
1993)\end{array}$ & Case series (20): Level 4 & Autologous bone marrow aspirate & $\begin{array}{l}20 \text { ununited long bone } \\
\text { fractures }\end{array}$ & $\begin{array}{l}17 \text { cases united in } 5(3-7) \\
\text { months }\end{array}$ \\
\hline $\begin{array}{l}\text { (Ateschrang et } \\
\text { al., 2009) }\end{array}$ & Case series (15): Level 4 & $\begin{array}{l}\text { Cancellous allogenic bone graft and } \\
\text { "vitalised" through the injection of } \\
\text { autologous bone marrow. }\end{array}$ & $\begin{array}{l}\text { Infected tibial } \\
\text { nonunions }\end{array}$ & $\begin{array}{l}\text { Infection control in } 14 \text { of } 15 \\
\text { patients, union in } 11 \text { out of } 15 \\
\text { patients }\end{array}$ \\
\hline $\begin{array}{l}\text { (Dallari et al., } \\
\text { 2007) }\end{array}$ & $\begin{array}{l}\text { Prospective, randomised, } \\
\text { trial (33): Level } 1\end{array}$ & $\begin{array}{l}\text { Lyophilised bone chips: with platelet } \\
\text { gel in } 11 \text {, with platelet gel and culture- } \\
\text { expanded autologous BMSCs in } 12 \text {, and } \\
\text { without gel as controls in } 10 \text { patients. }\end{array}$ & Tibial osteotomy & $\begin{array}{l}\text { Osseointegration significantly } \\
\text { better with platelet gel, or } \\
\text { with platelet gel and culture- } \\
\text { expanded autologous BMSCs, }\end{array}$ \\
\hline $\begin{array}{l}\text { (Gan et al., } \\
\text { 2008) }\end{array}$ & Case series (41): Level 4 & $\begin{array}{l}\text { Autologous bone-marrow MSCs with } \\
\beta \text {-TCP }\end{array}$ & Spine fusion & $\begin{array}{l}\text { After } 34.5 \text { months, } 39 \text { of } 41 \text { had } \\
\text { good spinal fusion results. }\end{array}$ \\
\hline $\begin{array}{l}\text { (Kitoh et al., } \\
\text { 2007) }\end{array}$ & $\begin{array}{l}\text { Prospective case control } \\
\text { study ( } 11,24 \text { long bone): } \\
\text { Level } 2\end{array}$ & $\begin{array}{l}\text { Culture-expanded autologous BMSCs } \\
\text { and PRP }\end{array}$ & $\begin{array}{l}\text { Distraction osteogenesis } \\
\text { in } 12 \text { femora and } 12 \\
\text { tibiae }\end{array}$ & $\begin{array}{l}\text { Bone healing significantly } \\
\text { accelerated in MSC/PRP group } \\
\text { than the control }\end{array}$ \\
\hline $\begin{array}{l}\text { (Neen et al., } \\
\text { 2006) }\end{array}$ & $\begin{array}{l}\text { Case control study (50): } \\
\text { Level } 3\end{array}$ & $\begin{array}{l}\text { Autologous bone-marrow with Type } 1 \\
\text { collagen/hydroxyapatite matrix }\end{array}$ & Spine fusion & $\begin{array}{l}\text { Compared with autogenous } \\
\text { bone grafting, equivalent results } \\
\text { for posterolateral lumbar fusion, } \\
\text { significantly lower in lumbar } \\
\text { interbody fusions. }\end{array}$ \\
\hline $\begin{array}{l}\text { (Rodriguez- } \\
\text { Collazo and } \\
\text { Urso, 2015) }\end{array}$ & $\begin{array}{l}\text { Case control study (20): } \\
\text { Level } 3\end{array}$ & BMAC and PRP & $\begin{array}{l}\text { Bimalleolar fracture } \\
\text { with Ilizarov device } \\
\text { fixation }\end{array}$ & $\begin{array}{l}\text { A significant difference in } \\
\text { the rate of complete healing } \\
(16 \pm 1.6 v s .24 \pm 1.3 \text { weeks }) \\
\text { compared with control group. }\end{array}$ \\
\hline $\begin{array}{l}\text { (Desai et al., } \\
\text { 2015) }\end{array}$ & $\begin{array}{l}\text { Cohort study (39): } \\
\text { Level } 2\end{array}$ & BMAC with DBM and/or rhBMP-2 & Tibial nonunion & $\begin{array}{l}\text { rhBMP-2 had a lower healing } \\
\text { rate compared to DBM. }\end{array}$ \\
\hline $\begin{array}{l}\text { (Murena et } \\
\text { al., 2014) }\end{array}$ & Case report (2) & $\begin{array}{l}\text { Cortical allograft combined with BMP-7 } \\
\text { and BMAC }\end{array}$ & Humeral nonunion & $\begin{array}{l}\text { Nonunion site healed at } \\
4 \text { months and } 8 \text { months } \\
\text { postoperatively. }\end{array}$ \\
\hline $\begin{array}{l}\text { (Liebergall et } \\
\text { al., 2013) }\end{array}$ & $\begin{array}{l}\text { Prospective, randomised, } \\
\text { trial (24): Level } 1\end{array}$ & $\begin{array}{l}\text { Sorted autologous BMSCs, PRP, mixed } \\
\text { with DBM }\end{array}$ & Distal tibial fractures & $\begin{array}{l}\text { Median time to union } 1.5 \\
\text { months in the intervention } \\
\text { group, } 3 \text { months in the control } \\
\text { group }\end{array}$ \\
\hline $\begin{array}{l}\text { (Qu et al., } \\
2015)\end{array}$ & Case series (9): Level 4 & BMAC in 3, umbilical cord MSCs (6) & Long bone nonunion & $\begin{array}{l}\text { Mean time to clinical healing } \\
\text { comparable in both groups }\end{array}$ \\
\hline
\end{tabular}

nonunion comparing autologous BMAC (three patients) and transplantation of umbilical cord MSCs in 6 patients. All patients were followed up for 36 months. The mean time to clinical healing was comparable in both groups $(\mathrm{Qu}$ et al., 2015). Liebergall et al. performed a randomised and prospective preliminary study of cell-based therapy for prevention of delayed fracture union on 24 consecutive patients who underwent operative treatment for distal tibial fractures. Intervention entailed aspirating iliac crest bone marrow and peripheral blood, yielding sorted CD105positive MSCs and PRP, respectively, which were mixed with DBM and injected under fluoroscopic control into the fracture site. The median time to union was 1.5 months in the intervention group and 3 months in the control group (Liebergall et al., 2013).

In summary, most reported studies are uncontrolled ones. There are a few prospective, randomised studies. Bone marrow aspirate, BMAC or culture-expanded MSCs were used for long bone nonunions, tibial osteotomies, distraction osteogenesis, spine fusion and fractures. Achievement of bony union and accelerated healing were reported using those various methods of application (Table 3). To be commercialised, immediately available cell therapeutics would be needed. As MSCs do not provoke the host T-cell response, allogeneic implantation of stem cells will be available as an off-the-shelf product (Tasso and Pennesi, 2009; Tse et al., 2003). However, data from clinical reports using allogeneic MSCs for bone regeneration must be obtained for them to be considered a viable option for treating bone defects.

\section{Stem cell application for the regeneration of articular} cartilage and treatment of osteoarthritis

Unlike bone, which is self-regenerating tissue, the case of articular cartilage presents a dilemma in regeneration of damaged tissue. AC has limited potential for selfregeneration, and damage to $\mathrm{AC}$ eventually leads to the development and progression of osteoarthritis (OA). The low intrinsic regeneration potential of $\mathrm{AC}$ has been attributed to the difficulty of progenitor cells to access the damaged site due to a lack of blood vessels and the inability of adjacent articular chondrocytes to migrate and produce matrix (Im, 2016; Vinatier et al., 2009). Accordingly, considerable resources in terms of time and money have been poured into research on regeneration of $\mathrm{AC}$ and treatment of OA. Adult stem cells, particularly MSCs, have emerged as a source for cartilage regeneration (Caplan, 2005). In addition to excellent proliferation and differentiation potential, MSCs possess immunomodulatory and anti-inflammatory functions by modulating $\mathrm{T}$ and $\mathrm{B}$ 
Table 4. Use of stem cells to treat osteochondral defects.

\begin{tabular}{|c|c|c|c|c|}
\hline References & $\begin{array}{l}\text { Form of reports } \\
\text { (number of } \\
\text { patients): Level } \\
\text { of evidence }\end{array}$ & $\begin{array}{l}\text { Used cell and location of } \\
\text { defect }\end{array}$ & $\begin{array}{l}\text { Additional procedure / } \\
\text { carrier or additional } \\
\text { substances }\end{array}$ & Key results \\
\hline $\begin{array}{l}\text { (Wakitani et } \\
\text { al., 2007) }\end{array}$ & $\begin{array}{l}\text { Case report (3): } \\
\text { Level } 4\end{array}$ & $\begin{array}{l}\text { Culture-expanded autologous } \\
\text { BMSCs/patellofemoral joint }\end{array}$ & $\begin{array}{l}\text { Collagen gel and } \\
\text { autologous periosteum or } \\
\text { synovium }\end{array}$ & $\begin{array}{l}1 \text { year after transplantation, complete coverage } \\
\text { of the defect. }\end{array}$ \\
\hline $\begin{array}{l}\text { (Kuroda et } \\
\text { al., 2007) }\end{array}$ & $\begin{array}{l}\text { Case report (1): } \\
\text { Level } 4\end{array}$ & $\begin{array}{l}\text { Culture-expanded autologous } \\
\text { BMSCs/medial femoral } \\
\text { condyle }\end{array}$ & $\begin{array}{l}\text { Autologous periosteum } \\
\text { and collagen gel }\end{array}$ & $\begin{array}{l}7 \text { months after surgery, the defect was filled } \\
\text { with a hyaline-like type of cartilage tissue. }\end{array}$ \\
\hline $\begin{array}{l}\text { (Haleem et } \\
\text { al., 2010) }\end{array}$ & $\begin{array}{l}\text { Case series (5): } \\
\text { Level } 4\end{array}$ & $\begin{array}{l}\text { Culture-expanded autologous } \\
\text { BMSCs / femoral condyles. }\end{array}$ & $\begin{array}{l}\text { Platelet-rich fibrin glue } \\
\text { and periosteal flap/ } \\
\text { ACL reconstruction and } \\
\text { microfracture in } 1 \text { patient }\end{array}$ & $\begin{array}{l}12 \text { months after transplantation complete filling } \\
\text { of the defects and complete surface congruity in } \\
3 \text { patients, incomplete congruity in } 2 \text { patients. }\end{array}$ \\
\hline $\begin{array}{l}\text { (Kasemki- } \\
\text { Jwattana et } \\
\text { al., 2011) }\end{array}$ & $\begin{array}{l}\text { Case report (2): } \\
\text { Level } 4\end{array}$ & $\begin{array}{l}\text { Culture-expanded autologous } \\
\text { BMSCs/lateral femoral } \\
\text { condyle }\end{array}$ & $\begin{array}{l}\text { ACL reconstruction/ } \\
\text { Collagen scaffold }\end{array}$ & $\begin{array}{l}\text { After follow-up of } 30-31 \text { months, good defect } \\
\text { filling, stiffness and incorporation into the } \\
\text { adjacent cartilage }\end{array}$ \\
\hline $\begin{array}{l}\text { (Nejadnik et } \\
\text { al., 2010) }\end{array}$ & $\begin{array}{l}\text { Case control study } \\
(72) \text { : Level } 3 \\
\end{array}$ & $\begin{array}{l}\text { Culture-expanded autologous } \\
\text { BMSCs/knee }\end{array}$ & Periosteal flap & No difference between ACI and BMSC. \\
\hline $\begin{array}{l}\text { (Giannini et } \\
\text { al., 2009) }\end{array}$ & $\begin{array}{l}\text { Case series (48): } \\
\text { Level } 4\end{array}$ & $\begin{array}{l}\text { BMAC/talar osteochondral } \\
\text { lesion }\end{array}$ & & $\begin{array}{l}\text { After a minimum follow-up of } 24 \text { months, } \\
\text { regenerated tissue and various degrees of } \\
\text { remodelling; none showed entirely hyaline } \\
\text { cartilage. }\end{array}$ \\
\hline $\begin{array}{l}\text { (Giannini et } \\
\text { al., 2010) }\end{array}$ & $\begin{array}{l}\text { Case control study } \\
(81) \text { :Level } 3\end{array}$ & $\begin{array}{l}\text { BMAC/ talar osteochondral } \\
\text { lesion }\end{array}$ & $\begin{array}{l}\text { Hyaluronic acid } \\
\text { membrane }\end{array}$ & $\begin{array}{l}\text { After } 1 \text { year, a similar pattern of improvement } \\
\text { for three techniques: open ACI (10), } \\
\text { arthroscopic ACI (46), and arthroscopic BMAC } \\
\text { transplantation (25). }\end{array}$ \\
\hline $\begin{array}{l}\text { (Gobbi et al., } \\
\text { 2011) }\end{array}$ & Case series (15) & BMAC & Collagen I/II matrix & $\begin{array}{l}\text { Significant improvement in all scores at the } \\
\text { final follow-up. MRI showed coverage of the } \\
\text { lesion with hyaline-like tissue in all patients. }\end{array}$ \\
\hline $\begin{array}{l}\text { (de Windt et } \\
\text { al., 2016) }\end{array}$ & $\begin{array}{l}\text { Prospective cohort } \\
\text { (9): Level } 2\end{array}$ & $\begin{array}{l}\text { Allogeneic MSCs mixed with } \\
\text { either } 10 \% \text { or } 20 \% \text { recycled } \\
\text { autologous chondrocytes }\end{array}$ & Fibrin glue & $\begin{array}{l}\text { At } 12 \text { months, significant improvement in } \\
\text { clinical outcome. Completely filled defects with } \\
\text { regenerated cartilage. Hyaline-like regeneration } \\
\text { with a high proteoglycans and type II collagen } \\
\text { contents. }\end{array}$ \\
\hline
\end{tabular}

cells and inducing anti-inflammatory factors, which may enhance their regenerative power (Abumaree et al., 2012; Im, 2016). Compared with the numerous in vitro and in vivo studies published in this field, few clinical studies have investigated the regeneration of $\mathrm{AC}$ and treatment of $\mathrm{OA}$.

\section{Stem cells for osteochondral defects}

While cytotherapy for cartilage regeneration began with autologous chondrocyte implantation (ACI), the advantages of MSCs are increasingly recognised; these include reduced morbidity associated with obtaining donor cells as well as elimination of problems associated with ACI (Bornes et al., 2014). Despite interest in their clinical application, few controlled studies have been performed, and no randomised controlled trial. Reported studies are prospective-case series, cohort and case-control studies, and case reports (Table 4).

Wakitani's group was the first to report on clinical application of MSCs for articular cartilage defects. They transplanted autologous culture-expanded BMSCs into nine full-thickness articular cartilage defects of the patello-femoral joints in the knees of three patients. Single-passaged cells were collected, embedded in a collagen solution $\left(5 \times 10^{6}\right.$ cells $\left./ \mathrm{mL}\right)$, gelated, transplanted into the defect and covered with autologous periosteum or synovium. Six months later, clinical symptoms had improved; this improvement was maintained over the 17-27 month follow-up period. Histology of one patient, 12 months after the transplantation, revealed repair of the defect by fibrocartilaginous tissue. Magnetic resonance imaging (MRI) of another patient, 1 year after transplantation, revealed complete coverage of the defect (Wakitani et al., 2007). The same group treated an $\mathrm{AC}$ defect in the weight-bearing area of the medial femoral condyle with autologous BMSCs prepared in the same manner in a patient. Seven months after surgery, arthroscopy revealed the defect to be covered with smooth tissue. Histologically, the defect was filled with a hyalinelike type of cartilage tissue, which stained positively with Safranin-O. One year after surgery, the clinical symptoms had improved significantly. The patient had re-attained his previous activity level and experienced neither pain nor other complications (Kuroda et al., 2007).

Haleem et al. reported a case series of culture-expanded autologous BMSCs transplanted into full-thickness cartilage defects of femoral condyles. MSCs were carried in platelet-rich fibrin glue, and implanted, and covered with periosteal flap in 5 knees of 5 patients. The symptoms of all patients improved over the follow-up period of 12 months. Functional scores for all patients showed statistically significant improvement at 6 and 12 months postoperatively. MRI of three patients, at 12 months postoperatively, revealed complete filling of the defects and complete surface congruity with native cartilage, whereas that of two patients showed incomplete congruity (Haleem et al., 2010). Kasemkijwattana reported the results of autologous BMSC implantation in two patients with large traumatic cartilage defects of the knee. BMSCs were 
re-implanted into the defects with a 3D collagen scaffold. After follow-up at 30-31 months, clinical evaluation showed significant improvement. The arthroscopic assessment showed good defect filling, stiffness and incorporation into the adjacent cartilage (Kasemkijwattana et al., 2011). An observational cohort study with a large number of patients was conducted to compare the clinical outcomes of treatment with first-generation ACI to that of treatment with autologous BMSCs. Seventy-two matched (lesion site and age) patients underwent cartilage repair using chondrocytes $(n=36)$ or BMSCs $(n=36)$. There was a significant improvement in the patients' quality of life after cartilage repair in both groups. However, there was no difference between the two groups in terms of clinical outcomes. The authors concluded that BMSCs are as effective as chondrocytes for articular cartilage repair, and have advantages in terms of requiring less knee surgery, reduced costs, and minimised donor-site morbidity (Nejadnik et al., 2010).

Besides cartilage defects in the knee joints, a group applied BMAC to repair of talar osteochondral lesions in 48 patients. After a minimum follow-up of 24 months (mean, 29 months; range, 24-35 months), the American Orthopaedic Foot and Ankle Society (AOFAS) score improved from 64.4 to 91.4. Histologic evaluation showed regenerated tissue and various degrees of remodelling; however, none showed entirely hyaline cartilage (Giannini et al., 2009). The same group compared the results of 81 patients (mean age $30 \pm 8$ years) who had post-traumatic osteochondral lesions of the talus larger than $1.5 \mathrm{~cm}^{2}$ and who underwent open autologous chondrocyte implantation (10 cases), arthroscopic autologous chondrocyte implantation (46 cases), and 'one-step' arthroscopic repair by BMAC transplantation (25 cases). For the arthroscopic repair techniques, a hyaluronic acid membrane was used to support cells. After 1 year, a similar pattern of improvement in AOFAS results was found for all three techniques. The use of BMACs permitted a marked reduction in procedure morbidity and costs, and was able to overcome all the drawbacks of previous repair techniques (Giannini et al., 2010).

Gobbi et al. determined the effectiveness of cartilage repair utilising BMAC and a collagen I/III matrix (Chondro-Gide, Geistlich, Wolhusen, Switzerland). They prospectively followed up, for 2 years, 15 patients (mean age, 48 years) who underwent surgery for grade IV cartilage lesions of the knee. Six of the patients had multiple chondral lesions; the average size of the lesions was $9.2 \mathrm{~cm}^{2}$. All patients underwent a mini-arthrotomy and concomitant transplantation with BMACs covered with the collagen matrix. Patients showed significant improvement in all scores at the final follow-up. Patients presenting single lesions and patients with small lesions showed greater improvement. MRI showed coverage of the lesion with hyaline-like tissue in all patients, in accordance with the clinical results. Hyaline-like histological findings were also reported for all specimens analysed (Gobbi et al., 2011).

De Windt et al. performed phase I /II clinical trial with allogeneic MSCs mixed with either $10 \%$ or $20 \%$ recycled autologous cartilage-derived cells to treat cartilage defects in 10 patients. At 12 months, all patients showed significant improvement in clinical outcome compared to baseline. MRI and second-look arthroscopies showed completely filled defects with regenerative cartilage tissue. Histological analysis indicated hyaline-like regeneration with a high concentration of proteoglycans and type II collagen. The regenerative tissue contained patient's-own DNA only, indicating paracrine effect of allogeneic MSCs (de Windt et al., 2016).

In summary, most reports describe good results of MSC implantation in treating cartilage defects, including symptomatic and functional improvement as well filling of defects. On the other hand, histological analysis indicates that true hyaline cartilage is rarely found in the regenerated tissue. Individual groups use different methods of implantation in terms of cell number and carrier materials. Furthermore, lack of controls makes it difficult to determine whether stem cell implantation is a significant, game-changing concept compared with other methods, such as ACI. A randomised, prospective clinical trial, preferably involving $>100$ patients and multiple centres, is necessary.

\section{Stem cells to treat osteoarthritis}

OA presents a greater pool of affected patients than osteochondral defects. Following the promising results of in vivo implantation of stem cells in large animal models of OA, sporadic case series began to be reported. However, as is the case with osteochondral defects, few studies have evaluated the clinical use of stem cells to treat OA. In two individual case reports of cartilage degeneration of the knee, Centeno et al. (Centeno et al., 2008a; Centeno et al., 2008b) demonstrated statistically significant changes in visual analogue-scale pain scores and cartilage volumes on MRI. Davatchi et al. reported the result of three knee OA patients who were injected with $8-9 \times 10^{6} \mathrm{MSCs}$. Clinical parameters improved in transplanted knees at 6 months. Then, they started gradually to deteriorate, but at 5 years remained improved compared to baseline values (Davatchi et al., 2015).

Wakitani et al. applied bone marrow MSCs to repair human articular cartilage defects in osteoarthritic knee joints as an additional procedure to a high tibial osteotomy (HTO). In 24 knees, of 24 patients with knee OA, culture-expanded MSCs embedded in collagen gel were transplanted into the articular cartilage defect in the medial femoral condyle and covered with autologous periosteum at the time of 12 high tibial osteotomies. The other 12 subjects served as cell-free controls. Although the clinical improvement was not significantly different, the arthroscopic and histological grading score was better in the cell-transplanted group than in the cell-free control group (Wakitani et al., 2002). Another group analysed the use of intra-articular injections of cultured autologous bone marrow MSC in conjunction with microfracture and medial opening-wedge HTO. Fifty-six knees in 56 patients with unicompartmental osteoarthritic knees and genu varum were randomly allocated to the cell-recipient group 
Table 5. Use of stem cells to treat osteoarthritis.

\begin{tabular}{|c|c|c|c|c|}
\hline References & $\begin{array}{l}\text { Form of reports / } \\
\text { Level of evidence }\end{array}$ & $\begin{array}{l}\text { Used cell and location of } \\
\text { defect }\end{array}$ & $\begin{array}{l}\text { Additional procedure / } \\
\text { carrier or additional } \\
\text { substances }\end{array}$ & Key results \\
\hline $\begin{array}{l}\text { (Centeno et } \\
\text { al., 2008a) }\end{array}$ & $\begin{array}{l}\text { Case report (1): } \\
\text { Level } 4\end{array}$ & $\begin{array}{l}\text { Culture-expanded autologous } \\
\text { BMSCs: Knee OA }\end{array}$ & $\begin{array}{l}\text { Hyaluronic acid, pulsed } \\
\text { ultrasound }\end{array}$ & $\begin{array}{l}\text { Increase in meniscus volume, decreased } \\
\text { modified VAS scores. }\end{array}$ \\
\hline $\begin{array}{l}\text { (Centeno et } \\
\text { al., 2008b) }\end{array}$ & $\begin{array}{l}\text { Case report (1): } \\
\text { Level } 4\end{array}$ & $\begin{array}{l}\text { Culture-expanded autologous } \\
\text { BMSCs: Knee OA }\end{array}$ & $\begin{array}{l}\text { Platelet lysate, } \\
\text { dexamethasone }\end{array}$ & $\begin{array}{l}\text { Decreased cartilage defect on medial } \\
\text { femoral condyle, decreased modified VAS } \\
\text { scores }\end{array}$ \\
\hline $\begin{array}{l}\text { (Davatchi et } \\
\text { al., 2015) }\end{array}$ & $\begin{array}{l}\text { Case report (4): } \\
\text { Level } 4\end{array}$ & $\begin{array}{l}\text { Culture-expanded autologous } \\
\text { BMSCs: Knee OA }\end{array}$ & & $\begin{array}{l}\text { Clinical parameters improved at } 6 \text { months, } \\
\text { remained better than baseline values at } 5 \\
\text { years. }\end{array}$ \\
\hline $\begin{array}{l}\text { (Wakitani et } \\
\text { al., 2002) }\end{array}$ & $\begin{array}{l}\text { Prospective, } \\
\text { randomised, trial } \\
(24) \text { : Level } 1 \\
\end{array}$ & $\begin{array}{l}\text { Culture-expanded autologous } \\
\text { BMSCs: medial femoral } \\
\text { defect in Knee OA }\end{array}$ & $\begin{array}{l}\text { Collagen sheet and } \\
\text { periosteal cover/ High tibial } \\
\text { osteotomy }\end{array}$ & $\begin{array}{l}\text { Arthroscopic and histological grading score } \\
\text { was better in the cell-transplanted group } \\
\text { than in the cell-free control group. }\end{array}$ \\
\hline $\begin{array}{l}\text { (Wong et al., } \\
\text { 2013) }\end{array}$ & $\begin{array}{l}\text { Prospective, } \\
\text { randomised, trial } \\
(56) \text { : Level } 1\end{array}$ & $\begin{array}{l}\text { Cultured autologous BMSC: } \\
\text { knee OA }\end{array}$ & $\begin{array}{l}\text { Microfracture and medial } \\
\text { opening-wedge HTO, } \\
\text { hyaluronic acid }\end{array}$ & $\begin{array}{l}\text { Cell-recipient group showed significantly } \\
\text { better clinical and MRI scores than the } \\
\text { control group. }\end{array}$ \\
\hline $\begin{array}{l}\text { (Vangsness et } \\
\text { al., 2014) }\end{array}$ & $\begin{array}{l}\text { Prospective, } \\
\text { randomised, trial } \\
(55) \text { : Level } 1 \\
\end{array}$ & Allogeneic BMSCs: Knee OA & Partial meniscectomy & $\begin{array}{l}\text { Significantly increased meniscal volume } \\
\text { with MSC injection. Significant reduction } \\
\text { in pain compared with those the control. }\end{array}$ \\
\hline (Pak, 2011) & $\begin{array}{l}\text { Case series (4): } \\
\text { Level } 4\end{array}$ & $\begin{array}{l}\text { Autologous adipose tissue- } \\
\text { derived stem cells: } 2 \text { knee } \\
\text { OA, } 2 \text { hip OA }\end{array}$ & & $\begin{array}{l}\text { Patients with knee OA showed an increased } \\
\text { medical meniscus height on MRI. }\end{array}$ \\
\hline $\begin{array}{l}\text { (Jo et al., } \\
2014)\end{array}$ & $\begin{array}{l}\text { Prospective cohort } \\
\text { (18): Level } 2\end{array}$ & $\begin{array}{l}\text { Autologous adipose tissue- } \\
\text { derived stem cells: Knee OA }\end{array}$ & & $\begin{array}{l}\text { IA injection of } 1.0 \times 10^{8} \text { ASCs into OA } \\
\text { knees improved knee joint function and } \\
\text { pain and reduced cartilage defects. }\end{array}$ \\
\hline
\end{tabular}

$(n=28)$ or control group $(n=28)$. All patients underwent HTO and microfracture. The cell-recipient group received intra-articular injection of cultured MSCs with hyaluronic acid 3 weeks after surgery, whereas the control group received only hyaluronic acid. After adjustment for age, baseline scores, and time of evaluation, the cell-recipient group showed significantly better clinical and MRI scores (Wong et al., 2013).

The ability of MSCs to promote meniscus regeneration following partial meniscectomy, and the effects of MSCs on osteoarthritic changes in the knee were investigated in 55 patients. A single injection $\left(50 \times 10^{6}\right.$ or $150 \times 10^{6}$ allogeneic $)$ was given within 7 to $10 \boldsymbol{d}$ after the meniscectomy while the control group received a sodium hyaluronate vehicle. Meniscal volume increased significantly - as determined by quantitative MRI - in patients treated with cell after 12 months. Patients with OA changes, who received MSCs, experienced a significant reduction in pain compared with those who received the control (Vangsness et al., 2014).

Along with bone marrow MSCs, adipose stem cells have received attention for cartilage regeneration. Extensive investigations on chondrogenesis from ASCs in the last 15 years provided the basis of clinical applications (Zuk et al., 2001). As with bone marrow MSCs, there is a paucity of controlled clinical investigations on regeneration of AC using ASCs. Pak et al. (Pak, 2011) used autologous adipose tissue derived stem cells in four patients, comprising two with knee OA and two with hip OA, which produced positive results. Twelve weeks after treatment, the patients with knee OA showed an increased medial meniscus height on MRI. A controlled, prospective study using injected ASCs to treat OA was performed by Jo et al. They enrolled 18 patients with knee OA. The phase I study consisted of three dose-escalation cohorts; low-dose $\left(1.0 \times 10^{7}\right.$ cells $)$, mid-dose $\left(5.0 \times 10^{7}\right)$, and high-dose $\left(1.0 \times 10^{8}\right)$ groups, with three patients each.
Phase II included nine patients receiving the high dose. The Western Ontario and McMaster Universities score improved 6 months after injection in the high-dose group. The size of the cartilage defect decreased, whereas the volume of cartilage increased in the medial femoral and tibial condyles of the high-dose group, based on MRI and arthroscopy. Histology demonstrated regeneration of thick, hyaline-like cartilage. They concluded that IA injection of $1.0 \times 10^{8}$ ASCs into OA knees improved knee joint function and pain, without causing adverse events and reduced cartilage defects by inducing regeneration of hyaline-like articular cartilage (Jo et al., 2014).

In summary, MSC injection has been applied to patients to treat $\mathrm{OA}$ by itself or in conjunction with additional surgical procedures including microfracture, high tibial osteotomy or partial meniscectomy. Hyaluronic acid, corticosteroid, or platelet lysate were also used along with stem cells in some studies. In addition to several uncontrolled studies, a few controlled studies using injection of either bone marrow-derived MSCs or ASCs reported regeneration of articular cartilage or meniscus as well as symptomatic improvement. However, it is too early to draw any conclusion from these studies at this time and further data will be needed in a greater pool of patients. Furthermore, several unsolved issues need to be addressed including the necessary number of injected cells, the need for multiple injection, the efficacy and safety of allogeneic cells versus autologous cells, and whether it could be applied in advanced OA.

\section{Stem cells for tendon regeneration}

While tendon have receive less attention than those of bone and cartilage in the field of regenerative medicine, bone-tendon junction disorders such as rotator cuff tear or 
lateral epicondylitis can be intractable problems. A small number of clinical trials have been published in this field.

\section{Rotator cuff tear}

Rotator cuff tears are frequent shoulder problems that are usually dealt with by surgical repair. Despite improved surgical techniques, the tendon-to-bone healing rate is unsatisfactory due to difficulties in restoring the delicate transitional tissue between bone and tendon (Gomoll et al., 2004; Valencia Mora et al., 2015). Although there is a lack of consensus as to whether the application of stem cells to enhance the rotator cuff healing is effective or not, some authors have developed different strategies for clinical application of the experimental findings.

Ellera Gomes et al. investigated the behaviour of rotator cuff tears treated with the conventional repair technique with the aid of autologous BMAC in 14 patients. A complete tear of the rotator cuff was repaired and augmented with BMSCs from iliac crest bone marrow aspirate. At 12 months, 12 of the 14 tears had healed, according to clinical and magnetic resonance imaging results (Gomes et al., 2012). Hernigou et al. evaluated the efficiency of biologic augmentation of rotator cuff repair with iliac crest BMSCs. The prevalence of healing and prevention of re-tears were correlated with the number of MSCs received at the tendon-to-bone interface. Forty-five patients in the study group received concentrated BMSCs as an adjunct to single-row rotator cuff repair at the time of arthroscopy. The average number of MSCs returned to the patient was 51,000 $\pm 25,000$. Bone marrow-derived MSC injection as an adjunctive therapy during rotator cuff repair enhanced the healing rate and improved the quality of the repaired surface, as determined by ultrasound and MRI. At the most recent follow-up of 10 years, intact rotator cuffs were found in $39(87 \%)$ of the 45 patients in the MSCtreated group, but just 20 (44\%) of the 45 patients in the control group (Hernigou et al., 2014).

The paucity of controlled studies makes it difficult to tell if the results of preclinical studies would be reproduced clinically. Further well-controlled clinical studies are thus warranted.

\section{Other tendinopathies}

Lateral epicondylitis (LE), or tennis elbow, is a condition in which the outer elbow becomes sore and tender at the lateral epicondyle. It is caused by degenerative conditions in wrist extensor tendon origin (Kraushaar and Nirschl, 1999). While most patients have spontaneous symptomatic improvement, continuing activity and avoiding mandatory rest may lead to permanent pain. One sixth of patients develop chronic diseases intractable to conservative managements (Coombes et al., 2010; Smidt et al., 2002). Allogeneic ASCs mixed with fibrin glue were injected into common extensor tendon lesions of 12 participants with chronic LE; 6 subjects each were administered $10^{6}$ or $10^{7}$ cells in $1 \mathrm{~mL}$. After 52 weeks of follow-up, VAS scores progressively decreased and elbow performance scores improved. Tendon defects also significantly decreased through this period (Lee et al., 2015).

Chronic patellar tendinopathy is a common problem, which may be associated with long and tedious clinical course. It is an overuse disorder, typically occurring in athletes who participate in sports that require jumping, including volleyball and basketball. The primary pathologic process in most painful tendons is degenerative rather than inflammatory, with failed reparative response and absence of inflammatory cells. Effective conservative intervention includes relative rest, addressing biomechanical issues, eccentric exercise, stretching and movement retraining (Reinking, 2016). Eight patients with chronic patellar tendinopathy were treated with BMAC. At 5-year followup, statistically significant improvement was seen for most clinical scores. Seven of eight patients thought that the results of the procedure were excellent although control patients and radiological data were lacking in this study (Pascual-Garrido et al., 2012). Further corroborating clinical studies on the stem cell treatment will need to confirm these positive results of stem cell application to treat tendinopathies.

\section{Perspectives}

The application of regenerative medicine for musculoskeletal disorders has become widespread, despite the relative lack of critical evidence supporting its efficacy. To date, the literature supporting stem cell-based therapies comprises mostly case reports or case series with small number of phase I-III clinical studies. Despite the want of strong clinical evidence, the use of these therapies continues to expand due to the need for novel, minimally invasive therapies to treat conditions. Therefore, highquality evidence, including from randomised clinical trials, is necessary to define the role of cell-based therapies in the treatment of musculoskeletal disorders.

Of bone regeneration, ONFH has been the greatest focus for cell therapy. However, most reported studies were uncontrolled and used BMAC. Prospective controlled studies using MSCs have recently been reported. More evidence will be accumulated to prove the effectiveness of stem cell treatment in arresting the progression of the disease. Large long-bone defect is the entity where regenerative medicine is most needed. Because of challenging nature of constructing a viable cell-scaffold composite, clinical application of stem cells is still in its incipient stage. Further advancement in tissue engineering will facilitate the application of stem cell treatment for large long-bone defect. Much preclinical investigation had been performed to provide a rationale for stem cell implantation for osteochondral defects. While promising results have been reported from sporadic clinical reports, an agreement on the number of cells and suitable carrier materials is desired at this time that will allow a prospective clinical study of large scale. Cell therapy for OA holds greater potential for stem cell therapy because of its larger pool of patients and irreversible nature of disease progression. In addition to a need for controlled studies to prove long-term efficacy, its mode of action should be defined on whether the injected cells actually differentiate into articular chondrocytes or merely exert paracrine effects. Paucity of clinical reports makes it difficult to provide a perspective on the stem cell therapy for tendon disease. Further studies 
are necessary which will corroborate the results of a few currently available reports.

As for any modality of clinical medicine, stem cell treatment requires an understanding of the underlying pathophysiology of the disease. It is imperative that clinicians who adopt these new strategies into their practices possess a good understanding of the natural course of the targeted disease. It is also important for treating clinicians to have an enhanced understanding of different cell sources, with analysis of the reported population of native stem and progenitor cells. Precise use of definitions and nomenclatures regarding cell sources and cell types is mandatory as well as differentiation between culture-expanded cells and native cells, and between autologous and allogeneic sources. It will also help to have a basic knowledge on the use and availability of methods for quantification and characterisation of the cells and the efficiency of harvest, processing and delivery procedures.

It is also highly recommended that treating physicians do not thrust aside the concomitant use of established measures until stem cell therapy is evidently proved worthy in terms of efficacy and cost.

\section{Acknowledgements}

This work was supported by a grant from the National Research Foundation funded by the Korean government (2015R1A2A1A09002793).

\section{References}

Abumaree M, Al Jumah M, Pace RA, Kalionis B (2012) Immunosuppressive properties of mesenchymal stem cells. Stem Cell Rev 8: 375-392.

Aoyama T, Goto K, Kakinoki R, Ikeguchi R, Ueda M, Kasai Y, Maekawa T, Tada H, Teramukai S, Nakamura T, Toguchida J (2014) An exploratory clinical trial for idiopathic osteonecrosis of femoral head by cultured autologous multipotent mesenchymal stromal cells augmented with vascularized bone grafts. Tissue Eng Part B Rev 20: 233-242.

Aro HT, Aho AJ (1993) Clinical use of bone allografts. Ann Med 25: 403-412.

Ateschrang A, Ochs BG, Ludemann M, Weise K, Albrecht D (2009) Fibula and tibia fusion with cancellous allograft vitalised with autologous bone marrow: first results for infected tibial nonunion. Arch Orthop Trauma Surg 129: 97-104.

Bolhofner BR (2010) Principles of nonunion treatment. In: Rockwood and Green's Fractures in Adults. (Eds. by R.W. Bucholz., C.M. Court-Brown, J.D. Heckman, P. Tornetta) Lippincott Williams and Wilkins.

Bornes TD, Adesida AB, Jomha NM (2014) Mesenchymal stem cells in the treatment of traumatic articular cartilage defects: a comprehensive review. Arthritis Res Ther 16: 432.

Caplan AI (2005) Review: mesenchymal stem cells: cell-based reconstructive therapy in orthopedics. Tissue Eng 11: 1198-1211.
Centeno CJ, Busse D, Kisiday J, Keohan C, Freeman M, Karli D (2008a) Regeneration of meniscus cartilage in a knee treated with percutaneously implanted autologous mesenchymal stem cells. Med Hypotheses 71: 900-908.

Centeno CJ, Busse D, Kisiday J, Keohan C, Freeman MM (2008b) Increased knee cartilage volume in degenerative joint disease using percutaneously implanted, autologous mesenchymal stem cells, platelet lysate and dexamethasone. Med Sci Monit Basic Res 9: 246-251.

Connolly JF, Guse R, Tiedeman J, Dehne R (1991) Autologous marrow injection as a substitute for operative grafting of tibial nonunions. Clin Orthop Relat Res 266: 259-270.

Coombes BK, Bisset L, Vicenzino B (2010) Efficacy and safety of corticosteroid injections and other injections for management of tendinopathy: a systematic review of randomised controlled trials. Lancet 376: 1751-1767.

Correia C, Grayson WL, Park M, Hutton D, Zhou B, Guo XE, Niklason L, Sousa RA, Reis RL, VunjakNovakovic G (2011) In vitro model of vascularized bone: synergizing vascular development and osteogenesis. PLoS One 6: e28352.

Dallari D, Savarino L, Stagni C, Cenni E, Cenacchi A, Fornasari P, Albisinni U, Rimondi E, Baldini N, Giunti A (2007) Enhanced tibial osteotomy healing with use of bone grafts supplemented with platelet gel or platelet gel and bone marrow stromal cells. J Bone Joint Surg Am 89: 2413-2420.

Daltro GC, Fortuna V, de Souza ES, Salles MM, Carreira AC, Meyer R, Freire SM, Borojevic R (2015) Efficacy of autologous stem cell-based therapy for osteonecrosis of the femoral head in sickle cell disease: a five-year follow-up study. Stem Cell Res Ther 6: 110.

Davatchi F, Sadeghi Abdollahi B, Mohyeddin M, Nikbin B (2015) Mesenchymal stem cell therapy for knee osteoarthritis: 5 years follow-up of three patients. Int J Rheum Dis Mar 19: 219-225

de Windt TS, Vonk LA, Slaper-Cortenbach IC, van den Broek MP, Nizak R, van Rijen MH, de Weger RA, Dhert WJ, Saris DB (2016) Allogeneic mesenchymal stem cells stimulate cartilage regeneration and are safe for singlestage cartilage repair in humans upon mixture with recycled autologous chondrons. Stem Cells 35: 256-264.

Desai P, Hasan SM, Zambrana L, Hegde V, Saleh A, Cohn MR, Lane JM (2015) Bone Mesenchymal stem cells with growth factors successfully treat nonunions and delayed unions. HSS J 11: 104-111.

Dufrane D, Docquier PL, Delloye C, Poirel HA, Andre W, Aouassar N (2015) Scaffold-free three-dimensional graft from autologous adipose-derived stem cells for large bone defect reconstruction: clinical proof of concept. Medicine (Baltimore) 94: e2220. doi: 10.1097/ MD.0000000000002220.

Eyb R, Kotz R (1987) The transtrochanteric anterior rotational osteotomy of Sugioka. Early and late results in idiopathic aseptic femoral head necrosis. Arch Orthop Trauma Surg 106: 161-167.

Ficat RP (1985) Idiopathic bone necrosis of the femoral head. Early diagnosis and treatment. J Bone Joint Surg Br 67: 3-9. 
Gan Y, Dai K, Zhang P, Tang T, Zhu Z, Lu J (2008) The clinical use of enriched bone marrow stem cells combined with porous beta-tricalcium phosphate in posterior spinal fusion. Biomaterials 29: 3973-3982.

Gangji V, De Maertelaer V, Hauzeur JP (2011) Autologous bone marrow cell implantation in the treatment of non-traumatic osteonecrosis of the femoral head: Five year follow-up of a prospective controlled study. Bone 49: 1005-1009.

Gangji V, Hauzeur JP (2009) Cellular-based therapy for osteonecrosis. Orthop Clin North Am 40: 213-221.

Garg NK, Gaur S, Sharma S (1993) Percutaneous autogenous bone marrow grafting in 20 cases of ununited fracture. Acta Orthop Scand 64: 671-672.

Giannini S, Buda R, Cavallo M, Ruffilli A, Cenacchi A, Cavallo C, Vannini F (2010) Cartilage repair evolution in post-traumatic osteochondral lesions of the talus: from open field autologous chondrocyte to bone-marrow-derived cells transplantation. Injury 41: 1196-1203.

Giannini S, Buda R, Vannini F, Cavallo M, Grigolo B (2009) One-step bone marrow-derived cell transplantation in talar osteochondral lesions. Clin Orthop Relat Res 467: 3307-3320.

Giannoudis PV, Dinopoulos H, Tsiridis E (2005) Bone substitutes: an update. Injury 36: S20-S27.

Gobbi A, Karnatzikos G, Scotti C, Mahajan V, Mazzucco L, Grigolo B (2011) One-step cartilage repair with bone marrow aspirate concentrated cells and collagen matrix in full-thickness knee cartilage lesions results at 2-year follow-up. Cartilage 2: 286-299.

Gomes JLE, Da Silva RC, Silla LM, Abreu MR, Pellanda R (2012) Conventional rotator cuff repair complemented by the aid of mononuclear autologous stem cells. Knee Surg Sports Traumatol Arthrosc 20: 373-377.

Gomez-Barrena E, Rosset P, Muller I, Giordano R, Bunu C, Layrolle P, Konttinen YT, Luyten FP (2011) Bone regeneration: stem cell therapies and clinical studies in orthopaedics and traumatology. J Cell Mol Med 15: 12661286.

Gomoll AH, Katz JN, Warner JJ, Millett PJ (2004) Rotator cuff disorders: recognition and management among patients with shoulder pain. Arthritis Rheum 50: 37513761.

Haleem AM, El Singergy AA, Sabry D, Atta HM, Rashed LA, Chu CR, El Shewy MT, Azzam A, Aziz MTA (2010) The clinical use of human culture-expanded autologous bone marrow mesenchymal stem cells transplanted on platelet-rich fibrin glue in the treatment of articular cartilage defects: a pilot study and preliminary results. Cartilage 1: 253-261.

Healey JH, Zimmerman PA, McDonnell JM, Lane JM (1990) Percutaneous bone marrow grafting of delayed union and nonunion in cancer patients. Clin Orthop Relat Res 256: 280-285.

Hernigou P, Beaujean F (2002) Treatment of osteonecrosis with autologous bone marrow grafting. Clin Orthop Relat Res 405: 14-23.

Hernigou P, Bernaudin F, Reinert P, Kuentz M, Vernant JP (1997) Bone-marrow transplantation in sickle-cell disease. Effect on osteonecrosis: a case report with a fouryear follow-up. J Bone Joint Surg Am 79: 1726-1730.
Hernigou P, Lachaniette CHF, Delambre J, Zilber S, Duffiet P, Chevallier N, Rouard H (2014) Biologic augmentation of rotator cuff repair with mesenchymal stem cells during arthroscopy improves healing and prevents further tears: a case-controlled study. Int Orthop 38: 18111818.

Hernigou P, Poignard A, Beaujean F, Rouard H (2005) Percutaneous autologous bone-marrow grafting for nonunions. Influence of the number and concentration of progenitor cells. J Bone Joint Surg Am 87: 1430-1437.

Hernigou P, Poignard A, Zilber S, Rouard H (2009) Cell therapy of hip osteonecrosis with autologous bone marrow grafting. Indian J Orthop 43: 40-45.

Hibi H, Yamada Y, Ueda M, Endo Y (2006) Alveolar cleft osteoplasty using tissue-engineered osteogenic material. Int J Oral Maxillofac Surg 35: 551-555.

Im GI (2013) Nonviral gene transfer strategies to promote bone regeneration. J Biomed Mater Res A 101: 3009-3018.

Im GI (2015) Stem cells for reutilization in bone regeneration. J Cell Biochem 116: 487-493.

Im GI (2016) Regeneration of articular cartilage using adipose stem cells. J Biomed Mater Res A 104: 1830-1844.

Jo CH, Lee YG, Shin WH, Kim H, Chai JW, Jeong EC, Kim JE, Shim H, Shin JS, Shin IS (2014) Intra-Articular injection of mesenchymal stem cells for the treatment of osteoarthritis of the knee: a proof-of-concept clinical trial. Stem Cells 32: 1254-1266.

Jones EA, English A, Kinsey SE, Straszynski L, Emery P, Ponchel F, McGonagle D (2006) Optimization of a flow cytometry-based protocol for detection and phenotypic characterization of multipotent mesenchymal stromal cells from human bone marrow. Cytometry B Clin Cytom 70: 391-399.

Jones JP, Jr. (1994) Concepts of etiology and early pathogenesis of osteonecrosis. Instr Course Lect 43: 499512.

Kang JS, Moon KH, Kim BS, Kwon DG, Shin SH, Shin BK, Ryu DJ (2013) Clinical results of auto-iliac cancellous bone grafts combined with implantation of autologous bone marrow cells for osteonecrosis of the femoral head: a minimum 5-year follow-up. Yonsei Med J 54: 510-515.

Kasemkijwattana C, Hongeng S, Kesprayura S, Rungsinaporn V, Chaipinyo K, Chansiri K (2011) Autologous bone marrow mesenchymal stem cells implantation for cartilage defects: two cases report. J Med Assoc Thai 94: 395-400.

Kawate K, Yajima H, Ohgushi H, Kotobuki N, Sugimoto K, Ohmura T, Kobata Y, Shigematsu K, Kawamura K, Tamai K, Takakura Y (2006) Tissue-engineered approach for the treatment of steroid-induced osteonecrosis of the femoral head: transplantation of autologous mesenchymal stem cells cultured with beta-tricalcium phosphate ceramics and free vascularized fibula. Artif Organs 30: 960-962.

Kitoh H, Kitakoji T, Tsuchiya H, Katoh M, Ishiguro N (2007) Distraction osteogenesis of the lower extremity in patients with achondroplasia/hypochondroplasia treated with transplantation of culture-expanded bone marrow cells and platelet-rich plasma. J Pediatr Orthop 27: 629-634. 
Koo KH, Kim R, Ko GH, Song HR, Jeong ST, Cho SH (1995) Preventing collapse in early osteonecrosis of the femoral head. A randomised clinical trial of core decompression. J Bone Joint Surg Br 77: 870-874.

Kraushaar BS, Nirschl RP (1999) Tendinosis of the elbow (tennis elbow). Clinical features and findings of histological, immunohistochemical, and electron microscopy studies. J Bone Joint Surg Am 81: 259-278.

Kuroda R, Ishida K, Matsumoto T, Akisue T, Fujioka H, Mizuno K, Ohgushi H, Wakitani S, Kurosaka M (2007) Treatment of a full-thickness articular cartilage defect in the femoral condyle of an athlete with autologous bonemarrow stromal cells. Osteoarthritis Cartilage 15: 226-231.

Lee SY, Kim W, Lim C, Chung SG (2015) Treatment of lateral epicondylosis by using allogeneic adipose-derived mesenchymal stem cells: a pilot study. Stem Cells 33: 2995-3005.

Liebergall M, Schroeder J, Mosheiff R, Gazit Z, Yoram Z, Rasooly L, Daskal A, Khoury A, Weil Y, Beyth S (2013) Stem cell-based therapy for prevention of delayed fracture union: a randomized and prospective preliminary study. Mol Ther 21: 1631-1638.

Lim YW, Kim YS, Lee JW, Kwon SY (2013) Stem cell implantation for osteonecrosis of the femoral head. Exp Mol Med 45: e61. doi: 10.1038/emm.2013.128.

Ma Y, Wang T, Liao J, Gu H, Lin X, Jiang Q, Bulsara MK, Zheng M, Zheng Q (2014) Efficacy of autologous bone marrow buffy coat grafting combined with core decompression in patients with avascular necrosis of femoral head: a prospective, double-blinded, randomized, controlled study. Stem Cell Res Ther 5: 115.

Mao Q, Jin H, Liao F, Xiao L, Chen D, Tong P (2013) The efficacy of targeted intraarterial delivery of concentrated autologous bone marrow containing mononuclear cells in the treatment of osteonecrosis of the femoral head: a five year follow-up study. Bone 57: 509516.

Mao Q, Wang W, Xu T, Zhang S, Xiao L, Chen D, Jin $\mathrm{H}$, Tong P (2015) Combination treatment of biomechanical support and targeted intra-arterial infusion of peripheral blood stem cells mobilized by granulocyte-colony stimulating factor for the osteonecrosis of the femoral head: a randomized controlled clinical trial. J Bone Miner Res 30: 647-656.

Martin JR, Houdek MT, Sierra RJ (2013) Use of concentrated bone marrow aspirate and platelet rich plasma during minimally invasive decompression of the femoral head in the treatment of osteonecrosis. Croat Med J 54: 219-224.

Meijer GJ, de Bruijn JD, Koole R, van Blitterswijk CA (2008) Cell based bone tissue engineering in jaw defects. Biomaterials 29: 3053-3061.

Mesimaki K, Lindroos B, Tornwall J, Mauno J, Lindqvist C, Kontio R, Miettinen S, Suuronen R (2009) Novel maxillary reconstruction with ectopic bone formation by GMP adipose stem cells. Int J Oral Maxillofac Surg 38: 201-209.

Murena L, Canton G, Vulcano E, Surace MF, Cherubino $P$ (2014) Treatment of humeral shaft aseptic nonunions in elderly patients with opposite structural allograft, BMP-7, and mesenchymal stem cells. Orthopedics 37: e201-206.
Murrell WD, Anz AW, Badsha H, Bennett WF, Boykin RE, Caplan AI (2015) Regenerative treatments to enhance orthopedic surgical outcome. PM R 7: S41-52.

Neen D, Noyes D, Shaw M, Gwilym S, Fairlie N, Birch N (2006) Healos and bone marrow aspirate used for lumbar spine fusion: a case controlled study comparing healos with autograft. Spine 31: E636-E640.

Nejadnik H, Hui JH, Feng Choong EP, Tai BC, Lee EH (2010) Autologous bone marrow-derived mesenchymal stem cells versus autologous chondrocyte implantation: an observational cohort study. Am J Sports Med 38: 11101116.

Pak J (2011) Regeneration of human bones in hip osteonecrosis and human cartilage in knee osteoarthritis with autologous adipose-tissue-derived stem cells: a case series. J Med Case Rep 5: 296.

Pascual-Garrido C, Rolon A, Makino A (2012) Treatment of chronic patellar tendinopathy with autologous bone marrow stem cells: a 5-year-followup. Stem Cells Int 2012: 953510.

Persiani P, de Cristo C, Graci J, Noia G, GURZÌ M, Villani C (2015) Stage-related results in treatment of hip osteonecrosis with core-decompression and autologous mesenchymal stem cells. Acta Orthop Belg 81: 406-412.

Qu Z, Fang G, Cui Z, Liu Y (2015) Cell therapy for bone nonunion: a retrospective study. Minerva Med 106: 315-321.

Quarto R, Mastrogiacomo M, Cancedda R, Kutepov SM, Mukhachev V, Lavroukov A, Kon E, Marcacci M (2001) Repair of large bone defects with the use of autologous bone marrow stromal cells. N Engl J Med 344: 385-386.

Røsland GV, Svendsen A, Torsvik A, Sobala E, McCormack E, Immervoll H, Mysliwietz J, Tonn J-C, Goldbrunner R, Lønning PE (2009) Long-term cultures of bone marrow-derived human mesenchymal stem cells frequently undergo spontaneous malignant transformation. Cancer Res 69: 5331-5339.

Reinking MF (2016) Current concepts in the treatment of patellar tendinopathy. Int J Sports Phys Ther 11: 854866.

Rodriguez-Collazo ER, Urso ML (2015) Combined use of the Ilizarov method, concentrated bone marrow aspirate (cBMA), and platelet-rich plasma (PRP) to expedite healing of bimalleolar fractures. Strategies Trauma Limb Reconstr 10: 161-166.

Rubio D, Garcia-Castro J, Martín MC, de la Fuente R, Cigudosa JC, Lloyd AC, Bernad A (2005) Spontaneous human adult stem cell transformation. Cancer Res 65: 3035-3039.

Sampson S, Botto-van Bemden A, Aufiero D (2015) Stem cell therapies for treatment of cartilage and bone disorders: osteoarthritis, avascular necrosis, and nonunion fractures. PM R 7: S26-32.

Sen MK, Miclau T (2007) Autologous iliac crest bone graft: should it still be the gold standard for treating nonunions? Injury 38 Suppl 1: S75-80.

Sen RK, Tripathy SK, Aggarwal S, Marwaha N, Sharma RR, Khandelwal N (2012) Early results of core decompression and autologous bone marrow mononuclear 
cells instillation in femoral head osteonecrosis: a randomized control study. J Arthroplasty 27: 679-686.

Shayesteh YS, Khojasteh A, Soleimani M, Alikhasi M, Khoshzaban A, Ahmadbeigi N (2008) Sinus augmentation using human mesenchymal stem cells loaded into a $\beta$-tricalcium phosphate/hydroxyapatite scaffold. Oral Surg Oral Med Oral Pathol Oral Radiol Endod 106: 203-209.

Smidt N, van der Windt DA, Assendelft WJ, Deville WL, Korthals-de Bos IB, Bouter LM (2002) Corticosteroid injections, physiotherapy, or a wait-and-see policy for lateral epicondylitis: a randomised controlled trial. Lancet 359: 657-662.

Stres HK, Krkovič M, Koder J, Maličev E, Marolt D, Drobnic M, Kregar-Velikonja N (2007) Mesenchymal stem cells: a modern approach to treat long bones defects. In: T.Jarm, P.Kramar, A.Zupanic (Eds.): Medicom 2007, IFMBE Proceedings 16, Springer-Verlag Berlin Heidelberg. pp 253-256.

Sugioka Y (1978) Transtrochanteric anterior rotational osteotomy of the femoral head in the treatment of osteonecrosis affecting the hip: a new osteotomy operation. Clin Orthop Relat Res: 191-201.

Tasso R, Pennesi G (2009) When stem cells meet immunoregulation. Int Immunopharmacol 9: 596-598.

Tiedeman JJ, Connolly JF, Strates BS, Lippiello L (1991) Treatment of nonunion by percutaneous injection of bone marrow and demineralized bone matrix: an experimental study in dogs. Clin Orthop Relat Res 268: 294-302.

Tomford WW, Starkweather RJ, Goldman MH (1981) A study of the clinical incidence of infection in the use of banked allograft bone. J Bone Joint Surg Am 63: 244-248.

Tse WT, Pendleton JD, Beyer WM, Egalka MC, Guinan EC (2003) Suppression of allogeneic T-cell proliferation by human marrow stromal cells: implications in transplantation. Transplantation 75: 389-397.

Valencia Mora M, Ruiz Iban MA, Diaz Heredia J, Barco Laakso R, Cuellar R, Garcia Arranz M (2015) Stem cell therapy in the management of shoulder rotator cuff disorders. World J Stem Cells 7: 691-699.

Vangsness CT, Jr., Farr J, 2nd, Boyd J, Dellaero DT, Mills CR, LeRoux-Williams M (2014) Adult human mesenchymal stem cells delivered via intra- articular injection to the knee following partial medial meniscectomy: a randomized, double-blind, controlled study. J Bone Joint Surg Am 96: 90-98.

Vinatier C, Bouffi C, Merceron C, Gordeladze J, Brondello JM, Jorgensen C, Weiss P, Guicheux J, Noel D (2009) Cartilage tissue engineering: towards a biomaterialassisted mesenchymal stem cell therapy. Curr Stem Cell Res Ther 4: 318-329.

Wakitani S, Imoto K, Yamamoto T, Saito M, Murata N, Yoneda M (2002) Human autologous culture expanded bone marrow mesenchymal cell transplantation for repair of cartilage defects in osteoarthritic knees. Osteoarthritis Cartilage 10: 199-206.

Wakitani S, Nawata M, Tensho K, Okabe T, Machida H, Ohgushi H (2007) Repair of articular cartilage defects in the patello-femoral joint with autologous bone marrow mesenchymal cell transplantation: three case reports involving nine defects in five knees. J Tissue Eng Regen Med 1: 74-79.

Wong KL, Lee KB, Tai BC, Law P, Lee EH, Hui JH (2013) Injectable cultured bone marrow-derived mesenchymal stem cells in varus knees with cartilage defects undergoing high tibial osteotomy: a prospective, randomized controlled clinical trial with 2 years' followup. Arthroscopy 29: 2020-2028.

Zhao D, Cui D, Wang B, Tian F, Guo L, Yang L, Liu B, Yu X (2012) Treatment of early stage osteonecrosis of the femoral head with autologous implantation of bone marrow-derived and cultured mesenchymal stem cells. Bone 50: 325-330.

Zuk PA, Zhu M, Mizuno H, Huang J, Futrell JW, Katz AJ, Benhaim P, Lorenz HP, Hedrick MH (2001) Multilineage cells from human adipose tissue: implications for cell-based therapies. Tissue Eng 7: 211-228.

Editor's note: As all the reviewer comments were incorporated into the text of the manuscript, there is no Discussion with Reviewers section for this review paper.

Editor's note: The Scientific Editor responsible for this paper was Martin Stoddart. 